\title{
Further Characterization of Genetically Distinct Groups of Acidovorax citrulli Strains
}

\author{
M. Zivanovic and R. R. Walcott
}

Department of Plant Pathology, The University of Georgia, Athens 30602.

Accepted for publication 4 September 2016.

\begin{abstract}
Bacterial fruit blotch of cucurbits (BFB) is caused by the gram-negative bacterium Acidovorax citrulli, whose populations can be distinguished into two genetically distinct groups, I and II. Based on visual assessment of BFB severity on cucurbit seedlings and fruit after inoculation under greenhouse conditions, group I A. citrulli strains have been reported to be moderately to highly virulent on several cucurbit hosts, whereas group II strains have exhibited high virulence on watermelon but low virulence on other cucurbits. Additionally, group I strains are recovered from a range of cucurbit hosts, while group II strains are predominantly found on watermelon. The goal of this research was to develop tools to characterize and rapidly distinguish group I and II A. citrulli strains. We first sought to determine whether quantification of $A$. citrulli colonization of cucurbit seedling tissue reflects the differences between group I and II strains established by visual assessment of BFB symptom severity. Spray inoculation of melon seedlings with cell suspensions containing approximately $1 \times 10^{4} \mathrm{CFU} / \mathrm{ml}$

resulted in significantly higher $(P=0.01)$ population growth of M6 (group I; mean area under population growth curve $[\mathrm{AUPGC}]=43.73$ ) than that of AAC00-1 (group II; mean AUPGC $=39.33$ ) by 10 days after inoculation. We also investigated the natural spread of bacterial cells and the resulting BFB incidence on watermelon and melon seedlings exposed to three group I and three group II $A$. citrulli strains under mist chamber conditions. After 5 days of exposure, the mean BFB incidence on melon seedlings exposed to representative group II $A$. citrulli strains was significantly lower (25 and $3.98 \%$ in experiments 1 and 2, respectively) than on melon seedlings exposed to representative group I strains (94.44 and $76.11 \%$ in experiments 1 and 2, respectively), and on watermelon seedlings exposed to representative group I and II strains (70 to $93.33 \%$ ). Finally, we developed a polymerase chain reaction assay based on the putative type III secretion effector gene, Aave_2166, to rapidly distinguish group I and II A. citrulli strains. This assay will be important for future epidemiological studies on BFB.
\end{abstract}

Bacterial fruit blotch of cucurbits (BFB) is caused by the gramnegative bacterium Acidovorax citrulli (formerly A. avenae subsp. citrulli) (Schaad et al. 2008; Willems et al. 1992). Although the disease was first reported in the mid-1960s (Schaad et al. 1978), it gained importance in the late 1980 s when it caused up to $100 \%$ yield losses in commercial watermelon fruit production fields in several states in the United States (Latin and Rane 1990; Maynard and Hopkins 1999; Somodi et al. 1991; Wall and Santos 1988). Currently, BFB occurs sporadically on a range of cucurbit crops but, due to its destructive potential, it poses a serious threat to the production of cucurbit seed, seedling transplants, and fruit worldwide (Burdman and Walcott 2012).

A. citrulli populations can be distinguished into two groups (I and II) based on biochemical (carbon substrate utilization) and genetic analyses, including pulse-field gel electrophoresis (PFGE), repetitiveelement polymerase chain reaction (rep-PCR), and multilocus sequence typing (Burdman et al. 2005; Feng et al. 2009; Walcott et al. 2004). More recently, these groups have been shown to differ in their repertoire of type III secretion (T3S) effectors (Eckshtain-Levi et al. 2014). Additionally, a third group was identified, consisting of only two strains (ZUM4000 and ZUM4001) that were weakly virulent on watermelon, melon, and squash seedlings (Eckshtain-Levi et al. 2014). Group I and II A. citrulli strains differ in virulence on watermelon and nonwatermelon hosts (Burdman et al. 2005; Feng et al. 2009; O'Brien and Martin 1999; Walcott et al. 2004). Group I strains exhibit a moderate to high level of virulence on a range of cucurbits, whereas group II strains have been reported as highly virulent on watermelon but weakly virulent on other cucurbitaceous species (Burdman et al. 2005; O'Brien and Martin

Corresponding author: R. R. Walcott; E-mail address: rwalcott@uga.edu

(C) 2017 The American Phytopathological Society
1999; Walcott et al. 2004). To date, the difference in virulence between group I and II strains has been investigated based on disease severity on seedlings of various cucurbit species using visual rating scales (Burdman et al. 2005; Hopkins and Thompson 2002a; O'Brien and Martin 1999; Walcott et al. 2004). Disease severity rating scales have also been routinely used for assessing host plant resistance to BFB (Bahar et al. 2009; Hopkins and Thompson 2002a; Wechter et al. 2011). Unfortunately, these assays lack reproducibility across experiments and between laboratories. Having multiple independent evaluators that are trained to score BFB severity helps reduce the variability between experiments. Nevertheless, this approach does not allow comparisons of disease severity data across independent studies. Thus far, there have been no attempts to develop more precise assessment tools for A. citrulli aggressiveness. Several studies have used tissue colonization assays to assess the roles of specific genes in A. citrulli virulence (Johnson 2010; Johnson and Walcott 2013; Johnson et al. 2011); however, these assays have not been used to compare the virulence of group I and group II strains.

PFGE and rep-PCR have been routinely used to distinguish group I and II A. citrulli strains. Although PFGE is robust and highly discriminatory, it is also labor intensive and requires expensive equipment (Olive and Bean 1999). rep-PCR is less laborious than PFGE but it was reported to have lower discriminatory power for some bacteria (Olive and Bean 1999). A simple, rapid, and robust method to distinguish group I and II A. citrulli strains would greatly improve the efficiency of assessing the threat posed to specific cucurbit crop species. Hence, the objectives of this research were to develop reliable tools to characterize and rapidly distinguish group I and II $A$. citrulli strains. More specifically, our objectives were to (i) compare population growth dynamics of representative group I and group II $A$. citrulli strains on melon seedlings as the putative differential host, (ii) compare the relative incidence of BFB on 
watermelon and melon seedlings exposed to inoculum of group I and II A. citrulli strains under natural spread and infection conditions; and (iii) develop a PCR-based assay to rapidly distinguish group I and II A. citrulli strains.

\section{MATERIALS AND METHODS}

Host species and cultivars. Two-week-old seedlings of 'Crimson Sweet' watermelon and 'Joaquin Gold' melon were established in 250-ml plastic pots or 36- or 48-cell polystyrene flats (Speedling Inc., Sun City, FL) filled with pasteurized potting mix ( $90 \%$ composted pine bark and $10 \%$ vermiculite) under greenhouse conditions. Two-week-old seedlings were chosen because, at this stage, plants are highly susceptible to infection by A. citrulli. Additionally, 2-week-old seedlings are routinely used for virulence assays and resistance screens (Hopkins and Thompson 2002a).

Bacterial strains, growth conditions, and inoculum preparation. A. citrulli strains used in this study (Table 1) were grown routinely on nutrient agar (Difco, Becton, Dickinson and Co., Sparks, MD) for $48 \mathrm{~h}$ or in nutrient broth (NB) (EMD Chemicals Inc., Gibbstown, NJ) overnight at 28 to $30^{\circ} \mathrm{C}$. A c citrulli inoculum was prepared by adding cells from an overnight NB broth culture to sterilized distilled water. The cell suspension was adjusted to approximately $1 \times 10^{8} \mathrm{CFU} / \mathrm{ml}$ spectrophotometrically (optical density at $600 \mathrm{~nm}$ of approximately 0.3 ) (Spectronic 20; Bausch and Lomb, Rochester, NY) and 10-fold serial dilutions were conducted to generate the desired cell concentrations.

Temporal population dynamics of representative group I and II $A$. citrulli strains in melon cotyledons after spray inoculation. Temporal population dynamics of $A$. citrulli strains M6 (group I) and AAC00-1 (group II) were monitored on 2-weekold melon seedlings after spray inoculation with bacterial cell suspensions. Suspensions of each strain (approximately $1 \times 10^{4}$ $\mathrm{CFU} / \mathrm{ml}$ ) were sprayed onto seedlings until run-off and the plants were then placed in plastic bags and incubated in a growth chamber (Percival, Perry, IA) for $24 \mathrm{~h}$ at $30^{\circ} \mathrm{C}$ and approximately $100 \%$ relative humidity $(\mathrm{RH})$, with fluorescent light for $12 \mathrm{~h} /$ day. Subsequently, the plastic bags were removed and the seedlings were incubated in a growth chamber at $30^{\circ} \mathrm{C}$ and 70 to $80 \% \mathrm{RH}$ with $12 \mathrm{~h}$ of fluorescent light daily for nine additional days. A single cotyledon was collected from three plants at 4, 6, 8, and 10 days postinoculation (dpi). To eliminate surface inoculum, each cotyledon was placed in a separate tube with $10 \mathrm{ml}$ of sterilized distilled water and incubated with shaking at $30^{\circ} \mathrm{C}$ for $2 \mathrm{~h}$ at $200 \mathrm{rpm}$. Subsequently, the cotyledons were air dried on paper towels for several minutes, and three leaf disks ( $5 \mathrm{~mm}$ in diameter) were collected from each cotyledon. Each leaf disk was crushed in $500 \mu \mathrm{l}$ of sterilized distilled water and, after centrifugation for $3 \mathrm{~min}$ at $16,100 \times g$, the pellet was used for microbial DNA extraction using the Ultra Clean Microbial DNA Isolation Kit (MOBIO Laboratories Inc., Carlsbad, CA) according to the manufacturer's instructions, with the exception that the cells were lysed thermally at $65^{\circ} \mathrm{C}$ for $10 \mathrm{~min}$ with vortex mixing every 2 to $3 \mathrm{~min}$. A. citrulli populations in leaf disks were quantified by TaqMan real-time PCR (qPCR) using proprietary A. citrulli-specific primers and probe (UGA3979) at concentrations of 0.3 and $0.5 \mu \mathrm{M} /$ reaction, respectively. PCR amplification was conducted using the iQ Supermix reagent (BioRad Laboratories, Hercules, CA) according to the manufacturer's instructions and the following thermal profile: $95^{\circ} \mathrm{C}$ for $180 \mathrm{~s}$ and 40 cycles of $95^{\circ} \mathrm{C}$ for $20 \mathrm{~s}, 55^{\circ} \mathrm{C}$ for $30 \mathrm{~s}$, and $72^{\circ} \mathrm{C}$ for $30 \mathrm{~s}$. Cycle threshold values below 33 were recorded for each sample and converted into CFU/ disk based on a standard dilution curve (Fig. 1). Bacterial population data were plotted over time to generate population growth curves using Sigma Plot 10.0 (Systat Software Inc., San Jose, CA). Area under population growth curves (AUPGC) data were calculated and used to compare the population growth dynamics of each strain. The experiment was conducted twice. A generalized linear mixed model in analysis of variance (ANOVA) was used to test for interaction between experiment and strain. Due to the absence of significant interaction, fixed-effects
ANOVA was then performed on pooled data using the general linear model (GLM) procedure. All analyses were conducted in SAS (version SAS 9.2; SAS Institute Inc., Cary, NC).

Comparison of natural infection of watermelon and melon seedlings by representative group I and II $A$. citrulli strains. Six 2-week-old melon and watermelon seedlings were spray inoculated until run-off with cell suspensions (approximately $1 \times 10^{6} \mathrm{CFU} / \mathrm{ml}$ ) of representative group I (M6, AU9, and AAC98-17) and group II (AAC001, AAC94-21, and AAC206-102) A. citrulli strains. After inoculation, seedlings were placed in plastic bags and incubated at 20 to $25^{\circ} \mathrm{C}$ and $100 \% \mathrm{RH}$ for $24 \mathrm{~h}$, with 6 to $8 \mathrm{~h}$ of fluorescent and incandescent light daily. Subsequently, the bags were removed and the plants were transplanted into the center and corners of separate 36- or 48-cell planting trays containing alternately positioned, uninoculated 2-week-old watermelon and melon seedlings. Each planting tray contained 15 to 20 watermelon and 15 to 20 melon plants. Plants were incubated for 5 days in a mist chamber at 20 to $25^{\circ} \mathrm{C}$ and $>90 \% \mathrm{RH}$, with 6 to $8 \mathrm{~h}$ of fluorescent and incandescent light daily. The light cycle was altered relative to the spray-inoculation experiment to avoid inadvertent increases in temperature that occurred with prolonged light duration in the mist chamber. Seedlings were sprayed twice daily with a stream of sterilized water to promote splash dispersal of bacterial cells. The proportion of watermelon and melon seedlings showing at least one $\mathrm{BFB}$ lesion on cotyledons or leaves was recorded each day and the experiment was conducted twice. BFB incidence on melon and watermelon seedlings after 5 days of exposure to inoculum was compared for each experiment by conducting ANOVA using the GLM procedure. Additionally, a $t$ test of least significant difference was used for pairwise comparisons of relative BFB incidence. Statistical analyses were conducted in SAS (version SAS 9.2).

Development of a PCR assay to distinguish group I and II A. citrulli strains. Eckshtain-Levi et al. (2014) reported that the putative T3S effector, Aave_2166 (AvrBsT Xanthomonas euvesicatoria ortholog), was present in 12 group II A. citrulli strains, while 8 group I strains possessed a 123-bp deletion in this locus (from $72 \mathrm{bp}$ upstream to $51 \mathrm{bp}$ downstream of the predicted start codon). Based on this information, we designed two forward primers: G2AcFwd, a group II-specific primer, and G12AcFwd, a primer that amplified a portion of Aave_2166 in strains of both A. citrulli groups. One reverse primer, G12AcRev, was used with both forward primers and it annealed to template DNA 291 and $254 \mathrm{bp}$ downstream from G2AcFwd and G12AcFwd, respectively (Table 2; Fig. 2). The specificity of the PCR assay was evaluated using genomic DNA from 25 group I and 30 group II A. citrulli strains, ZUM4000 and ZUM4001 (recently identified group III A. citrulli strains), a strain of $A$. avenae (AAA99-2), and X. euvesicatoria (XCV04-01) (Table 1). Cells from a single colony of a 48-h-old culture of each strain were suspended in $50 \mu$ of sterilized distilled water, incubated at $100^{\circ} \mathrm{C}$ for $10 \mathrm{~min}$, and used as template DNA for PCR. Conventional PCR was conducted using MasterAmp Tfl DNA polymerase (Epicentre Biotechnologies, Madison, WI) according to the manufacturer's instructions. All primers were used at a concentration of $0.5 \mu \mathrm{M} /$ reaction, and the following thermal profile was employed: $95^{\circ} \mathrm{C}$ for $5 \mathrm{~min} ; 29$ cycles of $95^{\circ} \mathrm{C}$ for $30 \mathrm{~s}, 55^{\circ} \mathrm{C}$ for $40 \mathrm{~s}$, and $72^{\circ} \mathrm{C}$ for $30 \mathrm{~s} ; 95^{\circ} \mathrm{C}$ for $30 \mathrm{~s} ; 55^{\circ} \mathrm{C}$ for $40 \mathrm{~s}$; and $72^{\circ} \mathrm{C}$ for 5 min. For high-throughput screening, qPCR was conducted using SYBR Green Master Mix (Bio-Rad Laboratories) according to the manufacturer's instructions. All primers were used at the concentration of $0.3 \mu \mathrm{M} /$ reaction, and the following thermal profile was employed: $95^{\circ} \mathrm{C}$ for $120 \mathrm{~s}$ (optics off); 40 cycles of $95^{\circ} \mathrm{C}$ for $20 \mathrm{~s}$ (optics off), $55^{\circ} \mathrm{C}$ for $20 \mathrm{~s}$ (optics off), and $72^{\circ} \mathrm{C}$ for $30 \mathrm{~s}$ (optics on); and a melt curve analysis step (ramping from 60 to $95^{\circ} \mathrm{C}$ at $0.2^{\circ} \mathrm{C} / \mathrm{s}$ ).

\section{RESULTS}

Temporal population dynamics of representative group I and II $A$. citrulli strains in melon cotyledons after spray inoculation. Populations of the A. citrulli group I strain M6 were 
greater than those of the group II strain AAC00-1 in melon cotyledons at 4 and $6 \mathrm{dpi}$. However, at $8 \mathrm{dpi}$, populations of both strains reached approximately $1 \times 10^{7} \mathrm{CFU} / \mathrm{disk}$. Although mean AAC00-1 populations (approximately $1 \times 10^{7} \mathrm{CFU} /$ disk) were lower than those of M6 $\left(5 \times 10^{7} \mathrm{CFU} /\right.$ disk $)$ at $10 \mathrm{dpi}$, there was high variability in population estimates for both strains at this time point. M6 populations ranged from approximately $1 \times 10^{7}$ to approximately $5 \times 10^{7} \mathrm{CFU} /$ disk at each time point, while the population densities of AAC00-1 increased from approximately $1 \times 10^{6} \mathrm{CFU} /$ disk at $4 \mathrm{dpi}$ to approximately $1 \times 10^{7}$ $\mathrm{CFU} / \mathrm{disk}$ at 8 and $10 \mathrm{dpi}$ (Fig. 3A). AUPGC was significantly greater for M6 (mean AUPGC $=43.73$ ) than for AAC00-1 $($ mean AUPGC $=39.33)$ in melon cotyledons $(P=0.01)$ (Fig. 3B).

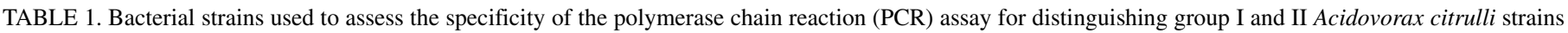

\begin{tabular}{|c|c|c|c|c|c|c|}
\hline \multirow[b]{2}{*}{ Strain } & \multirow[b]{2}{*}{ Host } & \multirow[b]{2}{*}{ Source } & \multirow[b]{2}{*}{ Haplotype ${ }^{b}$} & \multirow[b]{2}{*}{ Group } & \multicolumn{2}{|c|}{ PCR result ${ }^{\mathrm{a}}$} \\
\hline & & & & & $12 \mathrm{Ac}$ & $2 \mathrm{Ac}$ \\
\hline AAC00-1 & Citron & Walcott et al. 2000 & A1 (A) & II & + & + \\
\hline W1 & Watermelon & Burdman et al. 2005 & A1 (A) & II & + & + \\
\hline AAC94-21 & Watermelon & Walcott et al. 2000 & A3 (C) & II & + & + \\
\hline AAC $92-3$ & Watermelon & Walcott et al. 2000 & A4 (D) & II & + & + \\
\hline AAC $94-55$ & Watermelon & Walcott et al. 2000 & A5 (E) & II & + & + \\
\hline AAC $94-87$ & Watermelon & Walcott et al. 2000 & A6 (G) & II & + & + \\
\hline Tw16 & Watermelon & Eckshtain-Levi et al. 2014 & A6 (G) & II & + & + \\
\hline Tw148 & Watermelon & Eckshtain-Levi et al. 2014 & A6 (G) & II & + & + \\
\hline AAC94-39 & Watermelon & Walcott et al. 2000 & A7 (J) & II & + & + \\
\hline SaticoyB & Cantaloupe & Walcott et al. 2004 & A8 (Q) & II & + & + \\
\hline AAC $94-48$ & Watermelon & Walcott et al. 2000 & A9 (U) & II & + & + \\
\hline AAC201-12 & Watermelon & Walcott et al. 2004 & $\mathrm{~A} 10(\mathrm{~T})$ & II & + & + \\
\hline AAC205-22 & Watermelon & Ha et al. 2009 & A11 (W) & II & + & + \\
\hline AAC94-12 & Watermelon & Walcott et al. 2000 & A11 (W) & II & + & + \\
\hline AAC204-8 & Watermelon & This study & $\mathrm{A} 12(\mathrm{Z})$ & II & + & + \\
\hline AAC206-102 & Unknown & Ha et al. 2009 & A13 & II & + & + \\
\hline AAC208-20 & Watermelon & This study & A14 & II & + & + \\
\hline AAC208-19 & Watermelon & This study & A15 & II & + & + \\
\hline AAC205-14 & Watermelon & Ha et al. 2009 & A16 & II & + & + \\
\hline AAC211-36 & Watermelon & This study & A17 & II & + & + \\
\hline AAC210-13 & Unknown & This study & A18 & II & + & + \\
\hline $\mathrm{AAC} 212-30$ & Unknown & This study & A19 & II & + & + \\
\hline W6 & Watermelon & Burdman et al. 2005 & A20 & II & + & + \\
\hline AAC208-47 & Watermelon & This study & A21 & II & + & + \\
\hline AAC206-79 & Unknown & Ha et al. 2009 & $\mathrm{~A} 22$ & II & + & + \\
\hline $7 \mathrm{a} 1$ & Watermelon & Eckshtain-Levi et al. 2014 & A23 & II & + & + \\
\hline AAC211-29 & Unknown & This study & A24 & II & + & + \\
\hline AAC208-27 & Watermelon & This study & A25 & II & + & + \\
\hline AAC213-49 & Unknown & This study & A26 & II & + & + \\
\hline AAC210-11 & Unknown & This study & A 27 & II & + & + \\
\hline AAC203-51 & Unknown & This study & B1 & I & + & - \\
\hline AAC92-301 & Watermelon & Walcott et al. 2000 & B1 (F) & $\mathrm{I}$ & + & - \\
\hline AAC92-305 & Watermelon & Walcott et al. 2000 & B2 (I) & I & + & - \\
\hline AAC92-300 & Watermelon & Walcott et al. 2000 & B3 $(\mathrm{K})$ & I & + & - \\
\hline AU2 & Rockmelon & Walcott et al. 2000 & B4 (L) & $\mathrm{I}$ & + & - \\
\hline AU9 & Rockmelon & Walcott et al. 2000 & B5 (M) & I & + & - \\
\hline AAC206-94 & Melon & This study & B5 (M) & I & + & - \\
\hline AAC98-17 & Pumpkin & Walcott et al. 2000 & B6 (N) & I & + & - \\
\hline AAC99-5 & Cantaloupe & Walcott et al. 2004 & B7 (O) & I & + & - \\
\hline AAC $200-23$ & Watermelon & Walcott et al. 2004 & $\mathrm{~B} 8(\mathrm{P})$ & I & + & - \\
\hline AAC203-57 & Watermelon & Eckshtain-Levi et al. 2014 & B9 (R) & $\mathrm{I}$ & + & - \\
\hline AAC200-30 & Cantaloupe & Walcott et al. 2004 & $\mathrm{~B} 10(\mathrm{~S})$ & I & + & - \\
\hline AAC207-42 & Watermelon & This study & $\mathrm{B} 11(\mathrm{~V})$ & I & + & - \\
\hline AAC202-66 & Melon & Walcott et al. 2004 & $\mathrm{~B} 12(\mathrm{X})$ & $\mathrm{I}$ & + & - \\
\hline AAC203-11 & Watermelon & This study & $\mathrm{B} 13(\mathrm{Y})$ & $\mathrm{I}$ & + & - \\
\hline Tw76 & Melon & Eckshtain-Levi et al. 2014 & $\mathrm{~B} 13(\mathrm{Y})$ & $\mathrm{I}$ & + & - \\
\hline AAC207-41 & Unknown & This study & $\mathrm{B} 15$ & I & + & - \\
\hline AAC206-2 & Watermelon & Ha et al. 2009 & B16 & I & + & - \\
\hline AAC206-1 & Watermelon & Ha et al. 2009 & B17 & I & + & - \\
\hline AAC206-95 & Unknown & Ha et al. 2009 & B19 & $\mathrm{I}$ & + & - \\
\hline M1 & Melon & Burdman et al. 2005 & B21 & I & + & - \\
\hline 5 & Watermelon & Eckshtain-Levi et al. 2014 & B21 & I & + & - \\
\hline M6 & Melon & Burdman et al. 2005 & B21 & I & + & - \\
\hline AAC208-5 & Gourd & This study & $\mathrm{B} 22$ & $\mathrm{I}$ & + & - \\
\hline AAC208-26 & Watermelon & This study & $\mathrm{B} 23$ & $\mathrm{I}$ & + & - \\
\hline ZUM4000 & Watermelon & Eckshtain-Levi et al. 2014 & NA & III & + & + \\
\hline ZUM4001 & Watermelon & Eckshtain-Levi et al. 2014 & NA & III & + & + \\
\hline $\mathrm{XCV} 04-01^{\mathrm{c}}$ & Pepper & This study & ND & NA & - & - \\
\hline AAA99-2d & Maize & Fessehaie and Walcott 2005 & ND & NA & - & - \\
\hline
\end{tabular}

a $12 \mathrm{Ac}=\mathrm{G} 12 \mathrm{AcFwd} / \mathrm{G} 12 \mathrm{AcRev}$ and $2 \mathrm{Ac}=\mathrm{G} 2 \mathrm{AcFwd} / \mathrm{G} 12 \mathrm{AcRev}$.

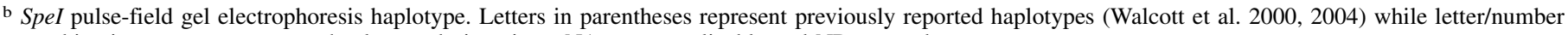
combinations represent current haplotype designations. NA $=$ not applicable and ND $=$ not done.

c Xanthomonas euvesicatoria.

d A. avenae. 


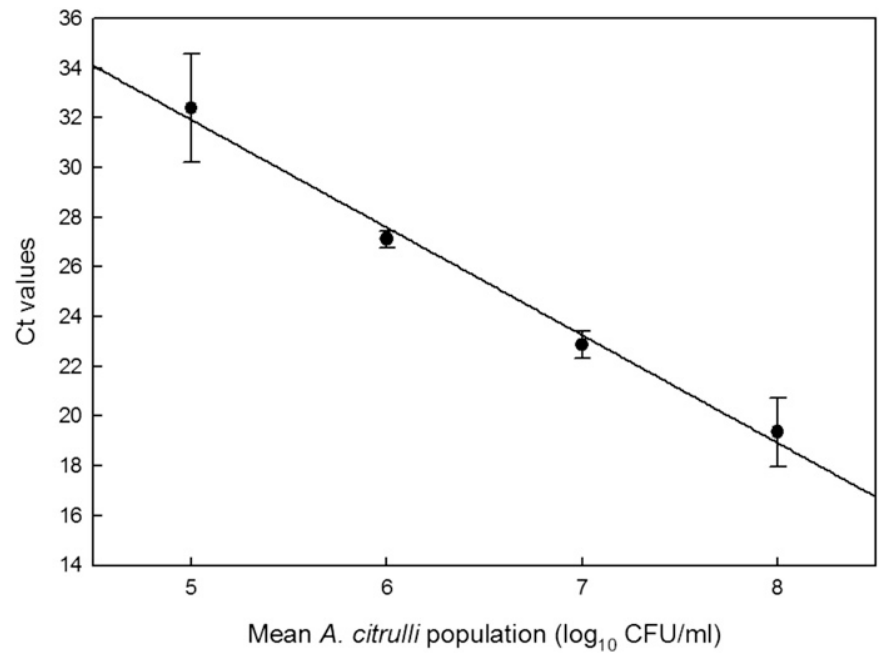

Fig. 1. Standard curve for converting cycle threshold $(\mathrm{Ct})$ values obtained by quantitative real-time polymerase chain reaction (qPCR) to the concentration of Acidovorax citrulli cells $\left(\log _{10} \mathrm{CFU} /\right.$ cotyledon disk). Cotyledon disks $(5 \mathrm{~mm}$ in diameter) from uninoculated 2-week-old watermelon seedlings were collected and macerated in $450 \mu \mathrm{l}$ of sterile water and spiked with $50 \mu \mathrm{l}$ of bacterial suspensions to obtain final concentrations ranging from $10^{5}$ to $10^{8}$ $\mathrm{CFU} / \mathrm{ml}$. Total microbial DNA was extracted and qPCR was conducted using an A. citrulli-specific TaqMan assay to obtain the $\mathrm{Ct}$ values. The experiment was performed four times. Linear regression was conducted and the equation for the regression line was used to calculate $\log _{10} \mathrm{CFU} /$ cotyledon disk.

TABLE 2. Sequences and functions of oligonucleotide primers used as components of a polymerase chain reaction assay for distinguishing group I and II Acidovorax citrulli strains

\begin{tabular}{lcc}
\hline Primer & DNA sequence $\left(5^{\prime} \rightarrow 3^{\prime}\right)$ & Function \\
\hline G2AcFwd & CGATAGGGTTGGGTTCAAG & $\begin{array}{c}\text { Group II-specific } \\
\text { forward primer }\end{array}$ \\
G12AcFwd & CCGAAGAGATAACACTGCATC & $\begin{array}{c}\text { Group I and II forward } \\
\text { primer } \\
\text { Group I and II reverse } \\
\text { primer }\end{array}$ \\
G12AcRev & ACGTACTGCCGATTTTTGC & \\
\hline
\end{tabular}

Comparison of natural infection of watermelon and melon seedlings by representative group I and II $A$. citrulli strains. To empirically investigate the differences in host preference between group I and II A. citrulli strains, we compared BFB incidence on watermelon and melon seedlings after exposure to three group I (M6, AAC98-17, and AU9) and three group II (AAC00-1, AAC206102, and AAC94-21) strains under conditions that facilitated natural bacterial spread and infection for 5 days. Mean BFB incidence on melon seedlings exposed to group II A. citrulli strains (25 and $3.98 \%$ in experiments 1 and 2 , respectively) was significantly lower $(P<0.0001$ and $P=0.004$ in experiments 1 and 2 , respectively) than for melon seedlings exposed to group I strains (94.44 and $76.11 \%$ in experiments 1 and 2, respectively). Mean BFB incidence on melon seedlings exposed to group II A. citrulli strains was also significantly lower than for watermelon seedlings exposed to group I and II strains (70 to 93.33\%) (Fig. 4). Additionally, there was a significant difference in the effects of group I and II strains on BFB incidence $(P<0.0001$ and $P=0.01$ in experiments 1 and 2 , respectively), as well as a significant host effect $(P=0.0002$ and 0.02 in experiments 1 and 2 , respectively). There was also a significant group-host interaction related to BFB incidence $(P=$ 0.0001 and 0.008 in experiments 1 and 2, respectively).

Discrimination of group I and II $A$. citrulli strains by PCR assay. Genomic DNA of $A$. citrulli strains M6 and AAC00-1 was amplified using a conventional PCR assay with primers designed in the current study. Using the group II-specific primer set (G2AcFwd/G12AcRev), the PCR assay yielded the expected 291-bp amplicon with genomic DNA from AAC00-1 but no amplicon was produced with genomic DNA from M6 (Fig. 5). The PCR assay conducted with the primer pair G12AcFwd/G12AcRev produced a 254-bp amplicon with genomic DNA from AAC00-1 and M6 (Fig. 5). A SYBR Green-based qPCR assay was used to evaluate additional group I and II A. citrulli strains, group III strains (ZUM4000 and ZUM4001), a strain of $A$. avenae, and a strain of $X$. euvesicatoria (Table 1). Using primers G2AcFwd/G12AcRev, all group II and III $A$. citrulli strains yielded the expected amplicon with a melting peak temperature of approximately $88^{\circ} \mathrm{C}$. In contrast, there was no amplification of DNA from the 25 group I strains tested with this primer set. Primer set G12AcFwd/G12AcRev

TTCTGCTGGGCCGATCGGTGCGAATGGACCAGCGTTGAAGTTTGCTCAGAGAAAGGTGGAAGCTTTCTGA ATATTTGCAATTGAGAATGGTTTATGAAGAATTTCATGCGATCGATAGGGTTGGGTTCAAGCAGGAGCAG TCGGCACGGCCGAAGAGATAACACTGCATCCGGACGAGGATCCACGTCTGCAGGATCGTCGAGTTCCGCC CACGGAAACTCCGGAGCACTCTCCGGCCTGTCGTCAAGAACTGCTGGAAGTGGAGAATTCGGGTTTCTGC CAGAGCGTCCCCGTCAGAдGGCAдTAGCTTTGCGCGAдGCACTGAACCGTGCGGAдAACACTCCTTCGGA CCTGCGGGCATATGCCGAGGCCGCATTGACAGCAGCAAAAATCGGCAGTACGTCAGACATGACGGATCTG GATGTGCAAAACAAGCAATACCTGGCCGATGCATACAACACCCGCTTCCCCGATCTCAAGCTGATTTGTC ATGATTCCGCTCAGGCGTTTTTCTCGGATTTCATGACTTCCGAAAAGCCGGTGTGGCGATCCCTCGTGCA GTTGAGCCCCCATAGCTTGCATCATGTGGCCATCGATGTTCGTTTGCAGGATGGGAAGCGCACGGCGGTG GTGTTGGAGCCGGCAATTGGCTATGGAATGAGGTCAGACGGGAAGATAACGATGCTGGCCGGATACGAAC CGCTGGGCAGGAдTATTCAGAAATATCTCGGAGAдAACGGCGATATGGCGGTCGTGCAGTTGGGGGCCCA GAAGTCGCATTACGACTGCATTATTTTTTCTTTGAATCTCGCCCTGTGTGCCTATCAGCGGGATGATGTG ATCGATGGTCTGCATGAAAGGCTTCGTGGGCATTACAGATGTTTTGCATCCGATGAAAATAAATCTCAAT TGCATCAGAдTATTGAATTTATAGACGGCACGACATTTTTGCCTCCGGTTTTTTTCAдACATTCGCACGC CAGGTCAACTATTTCTGAGGTTTTGGGGAATCAGCCTGACATATCGGATCGAAATGTCAGCACCGGGAAT GATAATCCCCGGGAAACGCTTTCCGAGCGGGTGGAAAATTTCCGTGTGGATCGAGGAGAAATGGCATGCA GCATGTCGATCGAAGCGTCACGTTTGAGAAAAATCAGARAAGCTATCGARTGATTGTCTGATGGGCATGG CGGGAACGAGTGCGCCGCAGCGTTAдAGGACGAACAAAGGCGGCAGTAAGGCAGTAGCTGAACTGGCTTG

Fig. 2. DNA sequence of Acidovorax citrulli gene Aave_2166 showing the relative positions of the group II-specific forward primer G2AcFwd (highlighted gray), the forward primer G12AcFwd that anneals to the portion of Aave_2166 in group I and II A. citrulli strains (underlined), and the reverse primer G12AcRev (highlighted gray, underlined); start and stop codons of Aave_2166 locus (solid black border). 
enabled amplification of genomic DNA from all tested A. citrulli strains, and all amplicons had the expected peak melting temperature of approximately $88^{\circ} \mathrm{C}$. Attempts to amplify genomic DNA from $A$. avenae and $X$. euvesicatoria yielded negative results using both primer sets (Table 1).

\section{DISCUSSION}

A. citrulli populations can be distinguished into at least two groups based on molecular and biochemical analyses and visual assessment of disease severity on various cucurbit hosts (Burdman et al. 2005; Feng et al. 2009; O'Brien and Martin 1999; Walcott et al. 2004). According to these studies, group I A. citrulli strains are moderately to highly virulent on a range of cucurbit species, whereas group II strains are highly virulent on watermelon but mildly aggressive on other cucurbits. To date, most of the assays used to screen for BFB resistance have relied on visual assessment
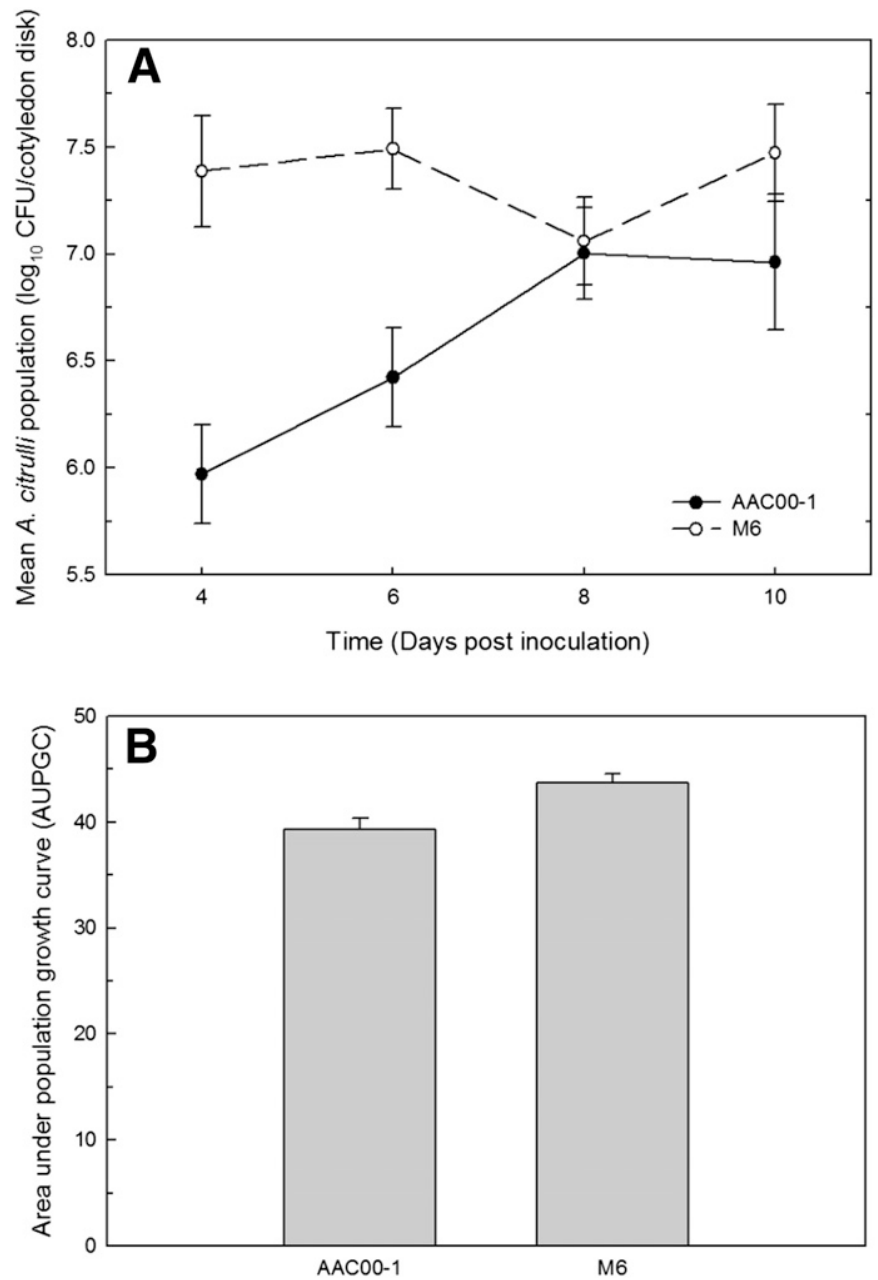

Fig. 3. A, Temporal population dynamics of Acidovorax citrulli strains M6 (group I) and AAC00-1 (group II) in melon seedlings after spray inoculation. Two-week-old melon seedlings were spray inoculated until run-off with cell suspensions containing each strain at approximately $1 \times 10^{4} \mathrm{CFU} / \mathrm{ml}$. Plants were incubated at $30^{\circ} \mathrm{C}$ and 70 to $80 \%$ relative humidity, with a 12-h light period, and three cotyledon disks were collected from three plants at 4, 6, 8, and 10 days after inoculation. Leaf disks were macerated and used for total microbial DNA extraction followed by quantitative real-time polymerase chain reaction using an A. citrulli-specific TaqMan assay. Data points represent means of the $\log _{10} A$. citrulli CFU/cotyledon disk and error bars represent the standard errors of the means. B, Bar chart of area under population growth curves (AUPGC) calculated for M6 and AAC00-1 on spray-inoculated melon seedlings. Bars represent mean AUPGC values and lines indicate standard errors of the means. Population growth of M6 was significantly higher $(P=$ $0.01)$ than that of AACO0-1. The experiment was conducted twice and pooled data are presented. of BFB severity using rating scales (Araújo et al. 2005; Hopkins and Thompson 2002b; O'Brien and Martin 1999). Unfortunately, these assays lack reproducibility across experiments and laboratories. Efforts to alleviate this variability include the use of multiple independent evaluators who are trained to score disease severity prior to data collection. However, this does not allow disease severity data to be compared across independent studies. For these reasons, we sought to determine whether quantification of $A$. citrulli colonization of cucurbit seedling tissue reflects the differences in virulence between group I and II strains with higher precision and reproducibility. We observed that, after cotyledon infiltration with bacterial cell suspensions (approximately $1 \times 10^{4} \mathrm{CFU} / \mathrm{ml}$ ), M6 and AAC00-1 reached similar population densities in watermelon and melon seedlings (data not shown). This suggests that, once in the plant apoplast, the differences in the arsenal of virulence factors possessed by the two strains do not affect tissue colonization. In contrast to our observations, Baltrus et al. (2012) reported that three closely related pathovars of Pseudomonas syringe (namely, $P$. syringe pv. phaseolicola $1448 \mathrm{a}$ and $1644 \mathrm{R}$ and $P$. syringae pv. glycinea R4), recovered from naturally infected French bean, mung bean, and soybean leaves, respectively, reached the highest population densities in their original hosts and significantly lower population densities in the nonhost species after leaf tissue infiltration with $10^{4} \mathrm{CFU} / \mathrm{ml}$. The authors further reported that the presence of two genes encoding the type III effectors hopCl and hopM1 and the absence of another (avrB2) contributed to the host range differences between pathovars glycinea and phaseolicola (Baltrus et al. 2012).

Because infiltration of bacterial cells into the plant apoplast does not reflect the natural infection process, we further hypothesized that quantifying $A$. citrulli population dynamics in seedling tissues

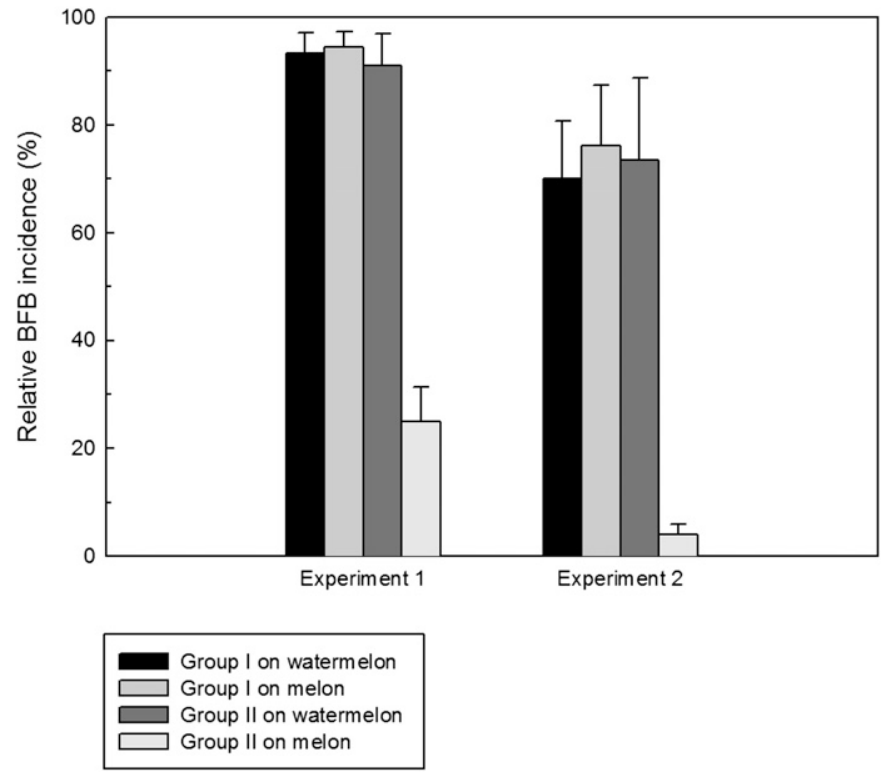

Fig. 4. Mean bacterial fruit blotch (BFB) incidence in a mixed population of watermelon and melon seedlings exposed to group I (M6, AAC98-17, and AU9) and group II (AAC00-1, AAC206-102, and AAC94-21) Acidovorax citrulli strains under conditions that facilitated natural spread of bacterial cells and infection. Each bar represents mean BFB incidence and error bars represent the standard errors of the means. Two-week-old melon and watermelon seedlings spray inoculated with group I and group II A. citrulli strains, respectively, were placed in the center and corners of separate seedling trays with mixed populations of uninoculated 2-week-old watermelon and melon seedlings. Seedlings were incubated at $>90 \%$ relative humidity and 20 to $25^{\circ} \mathrm{C}$ with light for 6 to $8 \mathrm{~h} /$ day and irrigated twice daily using a spray bottle. BFB incidence was recorded after 5 days of exposure, the experiment was conducted twice, and pooled data are presented; BFB incidence on melon seedlings exposed to group II strains was significantly lower $(P<0.0001$ and $P=$ 0.004 in experiments 1 and 2, respectively) than in any other treatment. 
after spray inoculation would better reflect the differences in virulence between group I and II strains on melon, the putative differential host. As expected, we found that the AUPGC was significantly greater for strain M6 than for AAC00-1 (Fig. 3B), which implied that M6 had a greater ability to survive on and penetrate into the apoplast of the melon cotyledons than AAC00-1. However, despite the observed differences, there was substantial variability in population densities of both strains between plants and sampling times. In addition, the assay is labor intensive and costlier than visual assessment of BFB severity and, therefore, would not serve as an adequate replacement.

Group I strains have been recovered from a range of cucurbits, whereas group II strains are mainly recovered from watermelon (Burdman et al. 2005; Feng et al. 2009; Walcott et al. 2004). Based on this observation, we hypothesized that, in a natural infection assay, BFB incidence would be lower on melon seedlings exposed to group II strains than in all other A. citrulli group-cucurbit host combinations. As hypothesized, the relative BFB incidence on melon seedlings after 5 days of exposure to group II strains was significantly lower than on melon seedlings exposed to group I, or watermelon seedlings exposed to group I and II strains (Fig. 4). It would be interesting to investigate the incidence of BFB on watermelon and melon fruit exposed to group I and II A. citrulli strains, because fruit infection might more clearly delineate host preference among the groups. It would also be informative to repeat the natural infection assays under field conditions. Knowing the potential of an A. citrulli strain to naturally infect different cucurbit species would inform growers of the risks associated with having different cucurbits in close proximity in seed, seedling transplant, and fruit production systems. Finally, the natural infection assay confirmed previous observations of reduced BFB incidence with group II strains on melon. Therefore, this relatively simple assay could be useful for characterizing new $A$. citrulli strains.

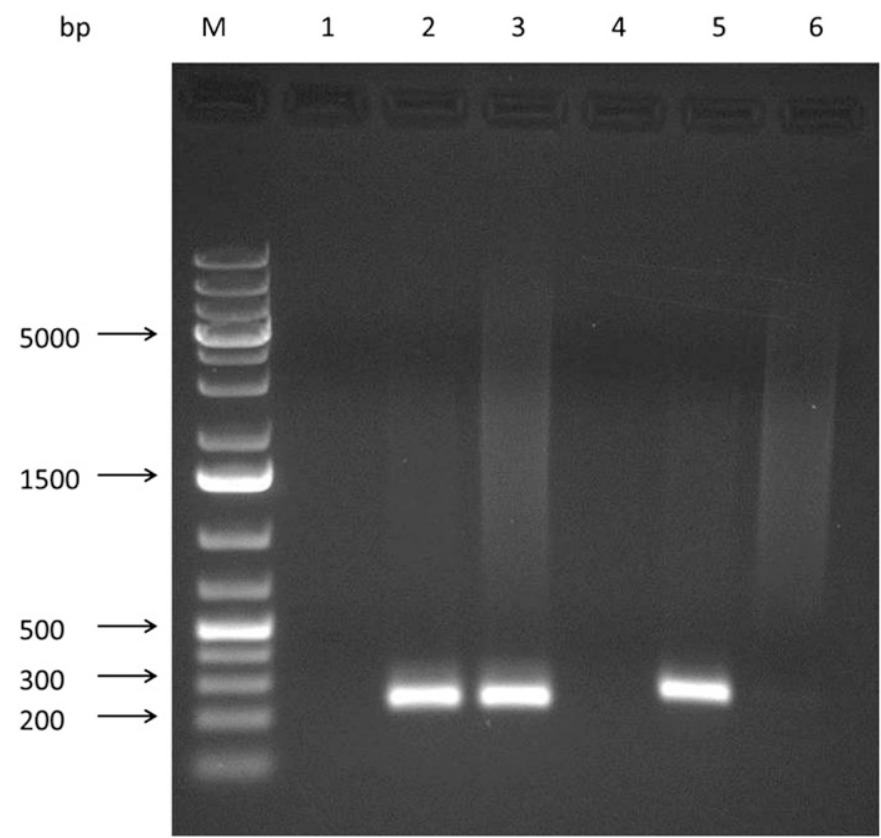

Fig. 5. Differentiation of Acidovorax citrulli groups by polymerase chain reaction (PCR) using primer pair G12AcFwd/G12AcRev that amplifies a portion of the Aave_2166 gene in group I and II strains, and primer pair G2AcFwd/ G12AcRev that amplifies a portion of Aave_2166 in group II strains only. Lane M contains a marker consisting of 15 chromatography-purified DNA fragments (ranging from 20,000 to $75 \mathrm{bp}$ ). PCR assay results obtained with the primer pair G12AcFwd/G12AcRev: lane 1, sterilized distilled water (negative control); lanes 2 and 3, genomic DNA of AAC00-1 (group II) and M6 (group I), respectively. PCR assay results obtained with the primer pair G2AcFwd/ G12AcRev: lane 4, sterilized distilled water; lanes 5 and 6, genomic DNA of AAC00-1 (group II) and M6 (group I), respectively.
Thus far, whole-genome restriction enzyme digestion followed by PFGE and rep-PCR have been used for distinguishing group I and II A. citrulli strains (Burdman et al. 2005; Walcott et al. 2004). Because these methods are laborious and require expensive equipment (especially PFGE), we sought to design primers to rapidly distinguish group I and II strains using the PCR assay. We designed a primer pair, G12AcFwd/G12AcRev, that amplified a portion of the Aave_2166 gene in all tested A. citrulli strains but yielded no amplicon with DNA from $A$. avenae and $X$. euvesicatoria. On the other hand, the group II-specific primer pair, G2AcFwd/ G12AcRev, yielded amplicons with genomic DNA from the tested group II strains. Unexpectedly, amplicons were produced with both primer pairs using DNA from the ZUM strains (group III), even though these strains were reported to lack the Aave_2166 gene (Eckshtain-Levi et al. 2014). The group III strains ZUM 4000 and ZUM4001 were isolated from watermelon seedlings in India and yielded variable results with $A$. citrulli-specific diagnostic PCR and serological assays. Unlike group I and II A. citrulli strains, SpeI restriction enzyme digestion of genomic DNA followed by PFGE failed to generate DNA fingerprints for the ZUM strains in multiple attempts. Additionally, rep-PCR DNA profiling clearly indicated a difference between group III and other representative $A$. citrulli strains (Eckshtain-Levi et al. 2014). Nevertheless, these strains were confirmed as A. citrulli by DNA-DNA hybridization assays. One explanation for the generation of an amplicon with the group IIspecific primer set designed in this study is that a variant of the Aave_2166 locus is present in the ZUM strains, even though it was not detected by Eckshtain-Levi et al. (2014). To detect the Aave_2166 locus in the ZUM strains, Eckshtain-Levi et al. (2014) used three different forward primers in combination with a single reverse primer. Even though these combinations of primers yielded no amplicon with group III strains, it is possible that the ZUM strains possess polymorphisms in the Aave_2166 flanking sequences (possibly complementary to the reverse primer) that prevented hybridization and subsequent amplification of the Aave_2166 gene. This could explain why the primers designed in this study, that target internal regions of Aave_2166, generated an amplicon with DNA from the ZUM strains. Efforts are underway to sequence the genomes of one the ZUM strains, which will yield insight into this discrepancy. Nevertheless, the ZUM strains appear to be of limited distribution and epidemiological importance because they exhibited low virulence on watermelon, melon, and squash seedlings (Eckshtain-Levi et al. 2014).

Recently, Zhong et al. (2016) published a primer set designed based on the pilL gene of AACO0-1 to discriminate group I and II A. citrulli strains. Although this PCR assay generated amplicons from 51 of 52 group II strains, it also generated an amplicon from three group I strains (Zhong et al. 2018). One of these three strains, AAC200-23, was included in the current study and was accurately identified as a group I member by our PCR assay. Additionally, the currently described assay is superior to that described by Zhong et al. (2016) because it allows for the positive detection of group I and group II strains, rather than relying on a negative result for group I strain determination. Multiplexing the two PCR assays described in the current study using TaqMan-based technology could yield a highly effective tool for diagnostic purposes and epidemiological studies.

\section{ACKNOWLEDGMENTS}

This work was supported by research grant US-4734-14C from the United States-Israel Binational Agriculture Research and Development Fund.

\section{LITERATURE CITED}

Araújo, D. V., Mariano, R., and Michereff, S. J. 2005. Métodos de inoculação de Acidovorax avenae subsp. citrulli em melão. Summa Phytopathol. 31:69-73.

Bahar, O., Kritzman, G., and Burdman, S. 2009. Bacterial fruit blotch of melon: Screens for disease tolerance and role of seed transmission in pathogenicity. Eur. J. Plant Pathol. 123:71-83. 
Baltrus, D. A., Nishimura, M. T., Dougherty, K. M., Biswas, S., Mukhtar, M. S., Vicente, J., Holub, E. B., and Dangl, J. L. 2012. The molecular basis of host specialization in bean pathovars of Pseudomonas syringae. Mol. Plant-Microbe Interact. 25:877-888.

Burdman, S., Kots, N., Kritzman, G., and Kopelowitz, J. 2005. Molecular, physiological, and host-range characterization of Acidovorax avenae subsp. citrulli isolates from watermelon and melon in Israel. Plant Dis. 89:1339-1347.

Burdman, S., and Walcott, R. 2012. Acidovorax citrulli: Generating basic and applied knowledge to tackle a global threat to the cucurbit industry. Mol. Plant Pathol. 13:805-815.

Eckshtain-Levi, N., Munitz, T., Živanović, M., Traore, S. M., Spröer, C., Zhao, B., Welbaum, G., Walcott, R. R., Sikorski, J., and Burdman, S. 2014. Comparative analysis of type III secreted effector genes reflects divergence of Acidovorax citrulli strains into three distinct lineages. Phytopathology 104:1152-1162.

Feng, J. J., Schuenzel, E. L., Li, J. Q., and Schaad, N. W. 2009. Multilocus sequence typing reveals two evolutionary lineages of Acidovorax avenae subsp. citrulli. Phytopathology 99:913-920.

Fessehaie, A., and Walcott, R. R. 2005. Biological control to protect watermelon blossoms and seed from infection by Acidovorax avenae subsp. citrulli. Phytopathology 95:413-419.

Ha, Y., Fessehaie, A., Ling, K. S., Wechter, W. P., Keinath, A. P., and Walcott, R. R. 2009. Simultaneous detection of Acidovorax avenae subsp. citrulli and Didymella bryoniae in cucurbit seedlots using magnetic capture hybridization and real-time polymerase chain reaction. Phytopathology 99:666-678.

Hopkins, D., and Thompson, C. 2002a. Evaluation of Citrullus sp. germ plasm for resistance to Acidovorax avenae subsp. citrulli. Plant Dis. 86:61-64

Hopkins, D., and Thompson, C. 2002b. Seed transmission of Acidovorax avenae subsp. citrulli in cucurbits. HortScience 37:924-926.

Johnson, K. L. 2010. Elucidation of the molecular host-pathogen interactions that influence seed-to-seedling transmission of Acidovorax citrulli. Ph.D. dissertation, Department of Plant Pathology, University of Georgia, Athens.

Johnson, K. L., Minsavage, G. V., Le, T., Jones, J. B., and Walcott, R. R. 2011. Efficacy of a nonpathogenic Acidovorax citrulli strain as a biocontrol seed treatment for bacterial fruit blotch of cucurbits. Plant Dis. 95:697-704.

Johnson, K. L., and Walcott, R. R. 2013. Quorum sensing contributes to seedto-seedling transmission of Acidovorax citrulli on watermelon. J. Phytopathol. 161:562-573.

Latin, R. X., and Rane, K. K. 1990. Bacterial fruit blotch of watermelon in Indiana. Plant Dis. 74:331.
Maynard, D. N., and Hopkins, D. L. 1999. Watermelon fruit disorders. HortTechnology 9:155-161.

O'Brien, R. G., and Martin, H. L. 1999. Bacterial blotch of melons caused by strains of Acidovorax avenae subsp. citrulli. Aust. J. Exp. Agric. 39: 479-485.

Olive, D. M., and Bean, P. 1999. Principles and applications of methods for DNA-based typing of microbial organisms. J. Clin. Microbiol. 37:1661-1669.

Schaad, N. W., Postnikova, E., Sechler, A., Claflin, L. E., Vidaver, A. K., Jones, J. B., Agarkova, I., Ignatov, A., Dickstein, E., and Ramundo, B. A. 2008. Reclassification of subspecies of Acidovorax avenae as A. avenae (Manns 1905) emend., A. cattleyae (Pavarino, 1911) comb. nov., A. citrulli Schaad et al. 1978. comb. nov., and proposal of A. oryzae sp. nov. Syst. Appl. Microbiol. 31:434-446.

Schaad, N. W., Sowell, G., Goth, R. W., Colwell, R. R., and Webb, R. E. 1978. Pseudomonas pseudoalcaligenes subsp. citrulli. nov. Int. J. Syst. Bacteriol. 28:117-125.

Somodi, G. C., Jones, J. B., Hopkins, D. L., Stall, R. E., Kucharek, T. A., Hodge, N. C., and Watterson, J. C. 1991. Occurrence of a bacterial watermelon fruit blotch in Florida. Plant Dis. 75:1053-1056.

Walcott, R. R., Fessehaie, A., and Castro, A. C. 2004. Differences in pathogenicity between two genetically distinct groups of Acidovorax avenae subsp. citrulli on cucurbit hosts. J. Phytopathol. 152:277-285.

Walcott, R. R., Langston, D. B., Jr., Sanders, F. H., Jr., and Gitaitis, R. D. 2000. Investigating intraspecific variation of Acidovorax avenae subsp. citrulli using DNA fingerprinting and whole cell fatty acid analysis. Phytopathology 90:191-196.

Wall, G., and Santos, V. 1988. A new bacterial disease of watermelon in the Mariana Islands. Phytopathology 78:1-9.

Wechter, W. P., Levi, A., Ling, K.-S., Kousik, C., and Block, C. C. 2011. Identification of resistance to Acidovorax avenae subsp. citrulli among melon (Cucumis spp.) plant introductions. HortScience 46:207-212.

Willems, A., Goor, M., Thielemans, S., Gillis, M., Kersters, K., and Deley, J. 1992. Transfer of several phytopathogenic Pseudomonas species to Acidovorax as Acidovorax avenae subsp. avenae subsp. nov., comb. nov., Acidovorax avenae subsp. citrulli, Acidovorax avenae subsp. cattleyae, and Acidovorax konjaci. Int. J. Syst. Bacteriol. 42:107-119.

Zhong, J., Lin, Z.-Y., Ma, Y.-M., Gao, B.-D., Liu, H.-Q., Zhao, T.-C., and Schaad, N. W. 2016. Rapid discrimination between groups I and II of Acidovorax citrulli using a primer pair specific to a pill gene. J. Phytopathol. 164:558-562. 